Research, part of a Special Feature on Applied Research for Enhancing Human Well-Being and Environmental Stewardship: Using Complexity Thinking in Southern Africa

\title{
Using Participatory Scenario Planning to Identify Ecosystem Services in Changing Landscapes
}

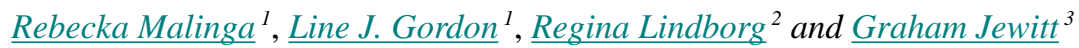

\begin{abstract}
There is a growing interest in assessing ecosystem services to improve ecosystem management in landscapes containing a mix of different ecosystems. While methodologies for assessing ecosystem services are constantly improving, only little attention has been given to the identification of which ecosystem services to assess. Service selection is mostly based on current state of the landscape although many landscapes are both inherently complex and rapidly changing. In this study we examine whether scenario development, a tool for dealing with uncertainties and complexities of the future, gives important insights into the selection of ecosystem services in changing landscapes. Using an agricultural landscape in South Africa we compared different sets of services selected for an assessment by four different groups: stakeholders making the scenarios, experts who have read the scenarios, experts who had not read the scenarios, and services derived from literature. We found significant differences among the services selected by different groups, especially between the literature services and the other groups. Cultural services were least common in literature and that list was also most dissimilar in terms of identity, ranking, and numbers of services compared to the other three groups. The services selected by experts and the scenario stakeholders were relatively similar indicating that knowledge of a study area gained through the scenario exercise is not very different from that of experts actively working in the area. Although our results show limited value in using scenario development for improved ecosystem service selection per se, the scenario development process triggers important discussions with local and regional stakeholders about key issues of today, helping to more correctly assess changes in the future.
\end{abstract}

Key Words: agriculture; complexity; ecosystem services; future; landscape; scenarios; social-ecological systems; South Africa; uncertainties

\section{INTRODUCTION}

There is a growing interest in assessing how complex landscapes generate multiple ecosystem services as a basis for improved ecosystem and land management (Bennett et al. 2009, Parrott and Meyer 2012). While many earlier ecosystem service assessments focus either on a single service in a specific place (Kühn et al. 2006, van Wilgen and De Lange 2011) or on the services generated from a specific ecosystem (Tottrup 2004) or biome (Smit et al. 2008), current research often addresses multiple services studies in real landscapes, containing a mix of social-ecological systems (Reyers et al. 2009, Raudsepp-Hearne et al. 2010, Lavorel et al. 2011). The methodological progress in ecosystem service analysis is developing rapidly (Carpenter et al. 2009, de Groot et al. 2010), but there has been little discussion of how to select the specific services to analyze in an assessment, despite the potential impact the service selection has on the outcome and application of the assessment.

Identifying relevant ecosystem services to assess is a fundamental step (Seppelt et al. 2012), but there is no standardized way of doing this. In the cases when the selection of relevant services is discussed, it is based on one, or a combination of some, of the following approaches: (1) literature reviews (Anderson et al. 2009), (2) data availability
(Raudsepp-Hearne et al. 2010, Rogers et al. 2010, Wendland et al. 2010), (3) case-specific needs, issues, and trends (Fisher et al. 2011), (4) local and national policy goals (Wendland et al. 2010, Fisher et al. 2011), (5) representation of ecosystem services categories (Posthumus et al. 2010, Raudsepp-Hearne et al. 2010), and (6) integrated knowledge of stakeholders (Reyers et al. 2009, O'Farrell et al. 2010, Willaarts et al. 2012).

Most assessments focus on ecosystem services that are known to be of current importance, unless the study specifically deals with the outcomes and trade-offs of a specific change process, such as the development of hydropower (Wang et al. 2010), or a water purification plant (Kane and Erickson 2007). However, ecosystem services generated from real landscapes constantly change as a result of complex interactions among several biophysical and social factors. Assessments that do not consider temporal dynamics could hence soon become outdated, if social-ecological dynamics are not taken into account. One way to account for complex and dynamic socialecological changes is by using scenario planning, a tool for dealing with the uncertainties and complexities of the future (Bennett and Zurek 2006, Kok et al. 2007). Scenario planning has been used to improve ecosystem management, from global (Alcamo et al. 2005, Millennium Assessment 2005) to local

\footnotetext{
${ }^{1}$ Stockholm Resilience Centre, Stockholm University, ${ }^{2}$ Department of Physical Geography and Quaternary Geology, Stockholm University, ${ }^{3}$ Centre for Water Resources Research, Umgeni Water Chair of Water Resources Management, University of KwaZulu-Natal
} 
scales (Peterson et al. 2003a, Bohensky et al. 2006, Nelson et al. 2009, Goldstein et al. 2012). By including a wide range of stakeholders, scenario planning can also capture case-specific needs and integrate a variety of perspectives (Reed et al. 2009).

The main objective of this study is to develop a set of qualitative scenarios in the Upper Thukela region in KwaZuluNatal, South Africa, where a future extended ecosystem services assessment is planned. South Africa is arguably one of the world's most dynamic and changing countries, being a relatively new democracy, with large inequalities in wealth and land ownership, as well as environmental and climatic challenges. The second objective is to analyze if scenario planning is a useful way of identifying relevant ecosystem services at the initial phase of an ecosystem services assessment. Together with local and regional stakeholders, we develop three scenarios for the future of the region. We use these scenarios to identify relevant ecosystem services for a regional future ecosystem service assessment. The services we identified are compared with an analysis of the services found in the literature on ecosystem service assessments in agricultural landscapes in Southern Africa, and with a selection of services that was carried out by experts not participating in the workshop.

We specifically address the following questions: (1) do scenario exercises envision a different set of ecosystem services to be included in ecosystem services assessments than the most common services found in literature? and (2) is scenario building a useful tool for capturing ecosystem services that are relevant to investigate in changing landscapes? We also discuss the potential usefulness, in general, of including scenario planning at an early stage in an ecosystem services assessment.

\section{SCENARIO PLANNING}

Scenario planning is a tool that can be used by various stakeholders for improving ecosystem management in the face of future uncertainties and complexities (Bennett and Zurek 2006, Kok et al. 2007). It can be useful for the management of complex social-ecological systems, since they integrate the effects that development can have on ecosystems and those that ecosystem change can have on development (Cumming et al. 2005). At a local level, they can highlight challenges and enhance opportunities for communities and regions to make decisions that consider changes in ecosystem services and their implications on human well-being (Wollenberg et al. 2000 $\mathrm{b}$, Carpenter et al. 2006). It has been suggested that scenario development should be included as a core part of environmental assessments (Whitfield and Reed 2012), and it is often part of frameworks that analyze social-ecological systems' long-term ability to provide ecosystem services (Walker et al. 2002).
Scenario planning as a tool emerged from military strategy and war planning and has been developed and used across a range of sectors, predominantly in business planning (Wollenberg et al. 2000a, van der Heijden 2005). Sciences of various disciplines use scenarios for different purposes, including trend analyses, forecasts, modeling and sensitivity analyses (Tress and Tress 2003). The approaches to develop scenarios vary greatly and range from strictly quantitative, using mathematical modeling and statistical forecasting, to qualitative, based on intuitive logic and creativity (Biggs et al. 2007). Scenarios that are presented as a set of different qualitative storylines can be used for exploring outcomes of alternative future developments, all of which are plausible (Bennett et al. 2003). These exploratory story lines are developed to be consistent and plausible narratives about the future that can capture current and future dynamics, integrating both social and ecological aspects, including management choices and their implications for development trajectories (Peterson et al. 2003b, Bennett and Zurek 2006, Kok et al. 2007, Rounsevell and Metzger 2010). They specifically focus on the analysis of the uncertainties and drivers of change (Wollenberg et al. 2000a). An analysis of their implications has the potential to capture complex relationships that are otherwise difficult to assess (Bohensky et al. 2006). Despite the complexity, the story lines strive to be comprehensive for scientists of various disciplines, as well as for decision makers and lay people (Enfors et al. 2008). Stakeholder participation in developing story lines varies from being expert driven (Bohensky et al. 2006, Nelson et al. 2009), to being driven mainly by local "grassroot" levels (Enfors et al. 2008).

\section{DEVELOPING SCENARIOS THROUGH SCENARIO PLANNING IN THE UPPER THUKELA}

\section{Case study description}

To test if scenario planning could be a useful tool to identify important ecosystem services in changing landscapes, we use the Upper Thukela region in South Africa, which is located in the Drakensberg mountain range near the border of Lesotho (Figure 1). The region covers approximately $3000 \mathrm{~km}^{2}$ and consists of 13 quaternary catchments (the fourth-order water resource management unit in South Africa (Department of Water Affairs 2011)) in the upper part of the Thukela River catchment. The mean annual precipitation ranges from around $550 \mathrm{~mm} /$ year in the lower valley regions to $2000 \mathrm{~mm} /$ year in parts of the Drakensberg Mountains, with an altitude of 3000 $\mathrm{m}$ above sea level (Lynch 2004). Approximately 150,000 people live in the region, with an average of 5.2 people per household (estimated from Statistics South Africa 2009). The region has two small towns or commercial centers, Bergville and Winterton, although the majority of the population lives in rural settings. The region hosts large-scale commercial and smallholder farming, as well as a World Heritage site and associated nature reserves adjacent to each other. The 
Fig. 1. The case study area in Upper Thukela, KwaZulu-Natal (eastern South Africa). The three major land user groups: a) smallholder subsistence farms, b) large-scale commercial farms and c) the Ukhahlamba Drakensberg Park are marked with arrows on the land cover map (derived from Landsat images from CSIR 2000) and visualized with photos, illustrating the large differences between landscapes with smallholder farmers and commercial farmers. Photos 1 and 2 were taken by R. Malinga (2009), and Photo 3 was obtained from Google maps (2009).

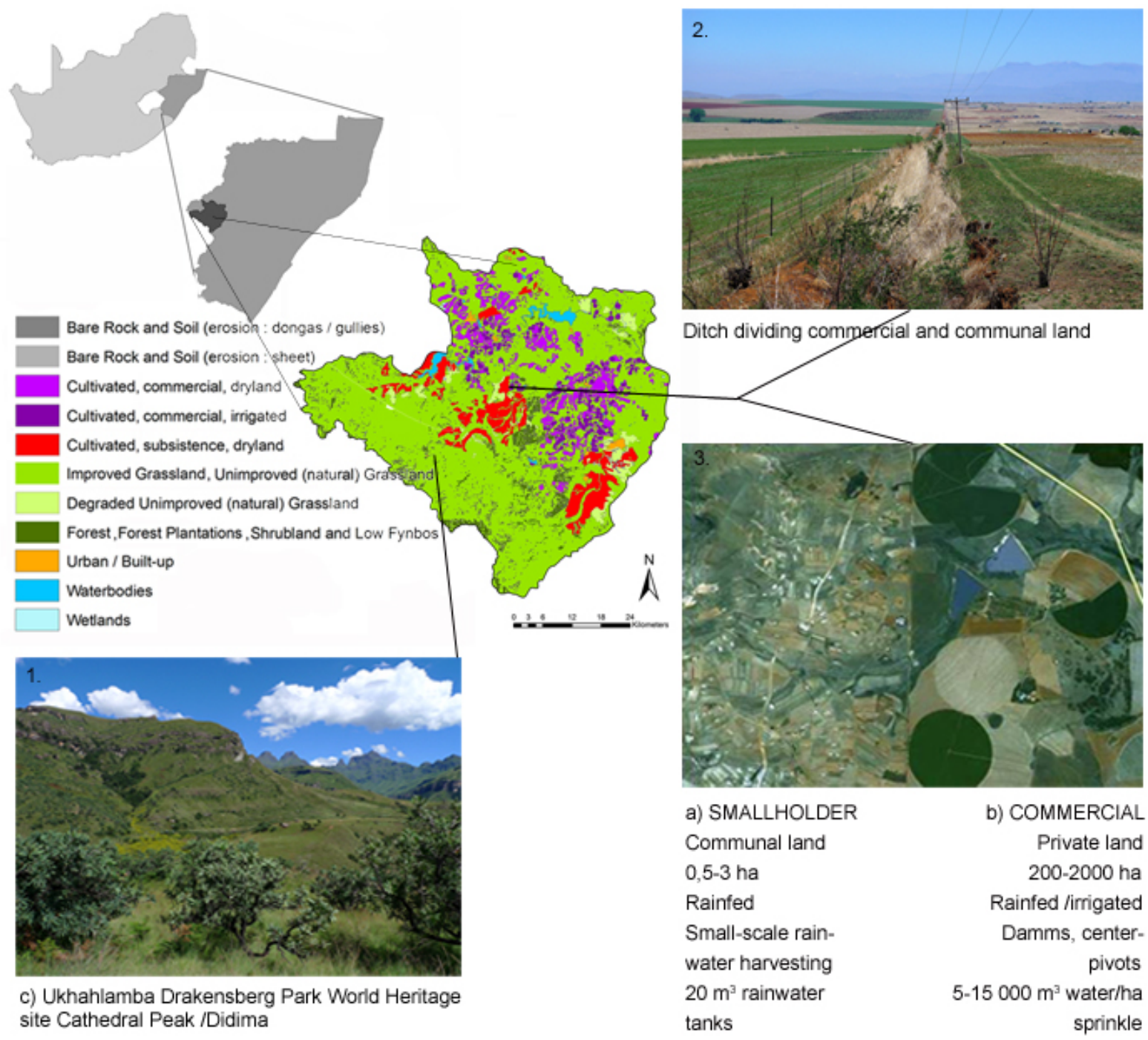

landscape hence provides a diversity of land uses and cultural identities. Landholdings by commercial farms are around 200-2000 ha, with sizes of crop fields around 25-200 ha (Figure 1). Smallholder agricultural lands are much more heterogenic, with homesteads and fields mixed in a mosaic landscape. Here, crop fields are 0.5-3 ha, and households, including 5-15 members, seldom have total landholdings larger than 5 ha. The landscape is dominated by grasslands that are either conservation areas (17\% of the total area), or managed for commercial or communal grazing (57\% of the total area) (Figure 1). Cropland is the second largest land use, and maize is the main crop produced among both commercial and smallholder farmers. Commercial croplands are dominated by large fields and dams. The dams are used for irrigation, which provides an opportunity for double cropping. The smallholder crop fields are rainfed, while vegetable gardens are watered by small-scale rainwater harvesting solutions. Tourism is important for the regional economy and 
the rural countryside, although most tourists mainly visit the nature reserves and national parks.

The Upper Thukela region, like many other places in South Africa, shows the legacy of the historical distribution of land during apartheid. White farmers took or were given large parts of the land, while the African people were given only small tracts of land for subsistence agriculture. Although some land has been transferred back to Africans, land ownership is still largely unequal. There are structural, biophysical, cultural, and historical constraints to development in the area and many people are trapped in poverty, with low production of their lands (Francis 2006). There are two distinctly different types of farming cultures located next to one another, with similar biophysical preconditions. The different farming practices and methods have evolved in parallel over several decades. The previously oppressed black majority is still, to a large extent, underprivileged and although the new democratic constitution and legislation are striving for equality, the process is very slow (Thornton 2009).

\section{Participatory Scenario Planning Approach}

The objective of the scenario planning exercise was to develop a set of alternative scenarios of social-ecological changes in the region, from which ecosystem services, that are prone to change, can be identified. We used a participatory scenario planning method, modified from Bennett and Zurek (2006) and Enfors et al. (2008), in which stakeholders are actively involved in developing the scenarios. The scenarios are developed as story lines of how the area changes until 2030 (i.e., over the next 20 years, from the time when the scenarios were developed). When we developed the scenarios, we also chose to focus on the general social and biophysical changes in the region and their effect on land use, rather than detailed changes in ecosystem services. This was done for three main reasons. First, it can require significant time to sensitize people about the concept of ecosystem services to a satisfying degree (Cowling et al. 2008). The majority of the participating stakeholders had not worked specifically with ecosystem services before. Secondly, this made the scenarios more broadly useful for other change processes in the organizations the stakeholders represented (e.g., local governmental organizations, NGOs and local municipalities). Finally, scenario development is a lengthy activity making it difficult to demand more time from participants.

The scenario development process consisted of four steps (Figure 2): initial interviews with local users (Figure 2, step 1), a workshop with stakeholders defining the main characteristics of the scenarios (Figure 2, step 2), drafting the scenarios (Figure 2, step 3), and then testing them with the local users and with internal, as well as external, stakeholders (Figure 2, step 4) in order to refine them.

First, semi-structured interviews were conducted with individuals or small groups (two to four participants) from the three categories of local stakeholders, i.e., small-scale subsistence farmers, large-scale commercial farmers, and representatives from nature reserves (Figure 2, step 1). We defined local users as people who work at a local scale and who have a broad knowledge of local conditions and prerequisites. The participants were identified by local community facilitators and researchers who have previously been involved in stakeholder analysis in the region and were therefore considered to have sufficient and intimate knowledge of the relevant stakeholders for this purpose (Reed et al. 2009). In total, 22 local users were interviewed. The interviews with subsistence farmers were facilitated by a translator. The main focus of the interviews was to identify drivers (socioeconomic/ cultural or biophysical/ environmental) that were perceived by the local users as possibly causing change in society during the coming 20 years, and that would have a potential influence on land management. The participants then ranked the identified drivers according to which were perceived to be the most important and the most uncertain (see Table A1.1 in Appendix 1).

Fig. 2. Conceptual model describing our scenario planning methodology for the scenario development in the Upper Thukela region. 1) Drivers of change were identified through interviews with local users, and 2) analyzed in a workshop with stakeholders working at regional and global scales. Key drivers were identified to form the starting points for three scenarios and the scenario outlines developed during the workshop were 3) finalized by the authors. 4) The scenarios were tested for consistency and plausibility by all stakeholder groups through an iterative process with the authors.

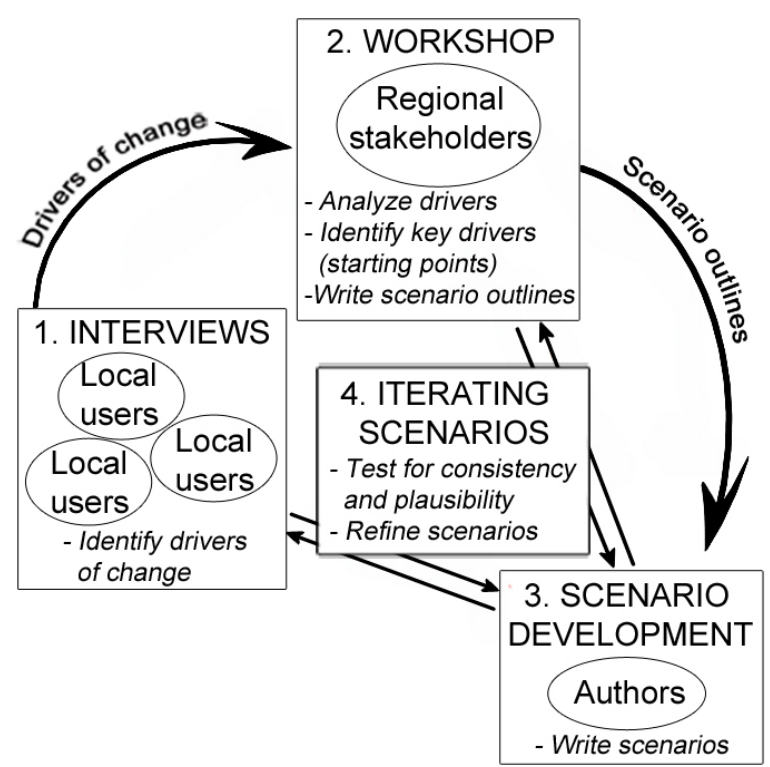


As a second step, we held a two-day scenario building workshop (Figure 2, step 2) with a wide range of stakeholders (researchers, policy makers, practitioners, resource managers, and resource users), with local, regional, and global knowledge and expertise. The workshop participants were identified through a combination of focus groups and snowball sampling (Reed et al. 2009). We interviewed four key informants, who identified relevant stakeholders for the workshop. These stakeholders were in turn asked to recommend further potential participants. The workshop participants were chosen because they have knowledge of the local area, while working at a regional to global level and thus they have a broad overview of drivers at the regional and global levels that affect local development. They are agricultural extensionists and consultants who work across the three land uses and are influenced by regional and national policies, as well as scientists who have conducted fieldwork in the region, and who have published at a national to international level. A total of 12 out of 25 invited stakeholders participated in the workshop. There was no overlap between the participants in the interviews and the workshop stakeholders.

In this process we integrated the outcomes from the interviews with local users with the experience of the people at the workshop. The drivers that were identified by the local users as the most uncertain and/or important (Table A1.1 in Appendix 1) shaped the basis of the discussions of the regional stakeholders during the workshop. These drivers played a significant role in the identification of the starting points of the scenarios, a process in which the workshop participants integrated the drivers identified by the local users with their own perception of drivers. The drivers were discussed and ranked by the participants. The five drivers that were ranked as most uncertain and/or important (security, enforcement of laws and agreements, investments, entrepreneurship, and climate) formed the starting points of the scenarios. They were combined in alternative ways, driving the future into three different and contrasting development trajectories (Table A1.2 in Appendix 1).

After setting the starting points of the scenarios, the participants developed the initial outlines of the scenarios that describe the year 2030 (Figure 2, step 2). Each scenario was aimed to be an internally consistent story that includes aspects about land use, agricultural production, infrastructure, tourism, equality, rural-urban dynamics, and livelihoods. Other drivers that were identified as important or uncertain by the local resource users, such as land reform, education, and infrastructure, were also used in the scenario development.

The full scenarios were completed and refined by the authors of this study (Figure 2, step 3). The scenarios were tested for consistency and plausibility by all stakeholder groups through an iterative process that included interviews, a survey, and a workshop in a smallholder community (Figure 2, step 4).
During this process the local stakeholders confirmed that the views they expressed during the initial interviews had been taken into account in the scenario development. A few external stakeholders were consulted in addition to previous participants.

The scenario exercise resulted in three plausible and contrasting scenarios called "Equal Environment", "Diverging Climate", and "Adaptive Collaboration". They highlight key issues and trends in the Upper Thukela region and describe different development possibilities over the coming 20 years. For key contrasts among the scenarios, see Appendix 2. Summaries of the scenarios are presented in Box 1, but please see Appendix 3 for the full scenarios.

\section{From scenarios to ecosystem services}

\section{Box 1: The Upper Thukela scenarios in short}

\section{Equal Environment}

In this scenario, the national government is devoted to sustaining the natural resource base of the country and invests substantially in the rural countryside. Rural communities are blooming and agricultural production among smallholders has increased remarkably. For commercial farmers, however, the situation has become more difficult due to higher input costs, taxes, and restrictions for water and chemical use. Smallholder farmers have, with support from the government, successfully increased their productivity and their shares of the agricultural market, and urbanization has slowed down slightly. Grassland and biodiversity management has improved across the whole region, also involving large- and small-scale farmers through agri-environmental schemes. Tourists are increasingly attracted to this region and improved tourist routes have increased the number of visitors.

\section{Diverging Climate}

In this scenario, the Upper Thukela has benefited from climate change. While the government is criticized for not investing enough in development, private investors take advantage of the improved weather conditions. Commercial farmers are winners, being quite flexible and adaptive to market fluctuations. Some farmers have entered a successful niche market of organic community produce. Many smallholder farmers still struggle with low agricultural productivity due to few rural investments and lack of knowledge and technology. This has contributed to a high level of migration from the region. Carbon offset funds have been developed and they also help secure biodiversity conservation in nature reserves. There are also attempts to improve grazing management among farmers. Increased crime (stock theft and cannabis trade), has, however, pushed grazing into more marginal and vulnerable grassland. Tourism has not developed in the rural areas, due to the reputation for crime, but continues to be substantial in the highly secure nature reserves.

\section{Adaptive Collaboration}

In this scenario, the Upper Thukela has suffered from extreme weather events, but the government does not have the resources to cover the losses. A collaborative spirit has awakened and people realize the benefits of dealing with issues together. Commercial farmers are generally less vulnerable, due to healthier grazing lands 
Table 1. The estimated change of 16 ecosystem services across the three scenarios, namely, Equal environment, Diverging climate and Adaptive collaboration, and for the land uses small-scale subsistence agriculture (SS), large-scale commercial agriculture (LC), and nature reserves (NR). A substantial increase in service generation is illustrated by,$++(+)$ for slight increase, (0) for no apparent change, (-) for slight decrease, (--) for substantial decrease of service generation, and (/) if the service is not relevant for a certain land use or in a certain scenario. The total change is calculated as the sum of all changes for each service (score).

\begin{tabular}{|c|c|c|c|c|c|c|c|c|c|c|}
\hline \multirow[t]{2}{*}{ Ecosystem service } & \multicolumn{3}{|c|}{ Equal environment } & \multicolumn{3}{|c|}{ Diverging climate } & \multicolumn{3}{|c|}{ Adaptive collaboration } & \multirow{2}{*}{$\begin{array}{c}\text { Total change } \\
\text { (score) }\end{array}$} \\
\hline & SS & $\mathrm{CL}$ & NR & SS & $\mathrm{CL}$ & NR & SS & $\mathrm{CL}$ & NR & \\
\hline Biodiversity & ++ & ++ & 0 & - & - & + & + & 0 & 0 & 8 \\
\hline Crop production & ++ & - & / & $+/ 0$ & + & l & - & - & / & 7 \\
\hline Cultural identity & + & - & + & - & $-/ 0$ & 0 & + & 0 & + & 7 \\
\hline Tourism & 0 & + & ++ & 0 & 0 & + & ++ & + & 0 & 7 \\
\hline Water quantity & + & + & 0 & + & 0 & + & - & - & - & 7 \\
\hline Carbon sequestration & ++ & + & 0 & $0 /+$ & 0 & + & $-/ 0$ & 0 & 0 & 6 \\
\hline Erosion regulation & ++ & + & 0 & 0 & 0 & + & - & 0 & 0 & 5 \\
\hline Livestock production & + & 0 & / & - & + & / & -- & 0 & / & 5 \\
\hline Water quality & - & + & 0 & 0 & - & 0 & - & 0 & 0 & 4 \\
\hline Biological pest control & + & + & l & 0 & - & l & 0 & 0 & I & 3 \\
\hline Nutrient regulation & ++ & 0 & 0 & 0 & - & 0 & 0 & 0 & 0 & 3 \\
\hline Pollination & + & + & I & 0 & - & I & 0 & 0 & / & 3 \\
\hline Wild foods & - & l & l & 0 & I & l & + & I & I & 2 \\
\hline Biofuel & 0 & 0 & I & 0 & + & I & 0 & 0 & I & 1 \\
\hline Other material & 0 & I & I & 0 & l & I & + & I & / & 1 \\
\hline Spiritual and religious & 0 & 0 & l & 0 & 0 & l & + & 0 & I & 1 \\
\hline
\end{tabular}

and irrigation systems, although their production has been very unreliable over the past two decades. Strong bonds between local farmers and NGOs create a new way of dealing with hardships for smallholder farmers, including the formation of agricultural cooperatives. There is also some collaboration between small- and large-scale farmers. Previously degraded grasslands have improved since the grazing pressure has decreased, due to the weather-induced death of livestock. Collaborative grazing management has also proven to be successful. The agricultural countryside attracts more and more tourists. Some smallholder farmers have opened up traditional African homestead guesthouses.

The three scenarios deal with general social and ecological changes that have implications for ecosystem services, but they do not explicitly describe how ecosystem services will change during the time period. The scenarios were used to identify relevant ecosystem services both by participants in the scenarios workshop and by external experts who had not developed the scenarios themselves.

\section{Scenario stakeholders}

A third of the stakeholders in the scenario workshop have substantial experience of working within the ecosystem services framework and this smaller group analyzed the scenarios (Appendix 3) in terms of ecosystem services change (Table 1). First, using the participants' previous experience of working in the region in combination with the outcomes of the discussions of the workshop, a list of 16 ecosystem services that are relevant and important today was identified (Table 1). These services were then thoroughly and methodically analyzed in terms of potential changes in each of the three scenarios. A matrix was used in which it was indicated whether a specific ecosystem service in a specific land use was assumed to change substantially (++ or --), slightly (+ or -), not to change much at all (0), or was not relevant $(/)$ (Table 1$)$. The proneness of a service to change was estimated as the sum of all assumed changes across the land uses and scenarios.

\section{External experts reading scenarios}

Second, we asked fourteen external experts on ecosystem services and scenarios, who were not involved with this study or with the scenario development, to read the scenarios (Appendix 3), the scenario contrasts (Appendix 2), and a brief description of the case study area. Eight experts agreed to participate, half of which have experience of fieldwork in South Africa. The selected experts are part of our extended research network working with ecosystem services and scenarios from Southern Africa, Europe, and North America. Based on the information given, they were asked to compile a list of five to ten important ecosystem services. We chose the interval five to ten services in order to capture the most common number of services in ecosystem services assessments (five) (Seppelt et al. 2011) and to limit the upper amount to ten to ensure that the experts prioritized the services. The answers from the experts who read the scenarios were gathered into one list that represents their collective view (Table A4.1 in Appendix 4), in total containing 20 different 
ecosystem services. Please see Appendix 4 for a detailed description of how the list was compiled.

\section{External experts not reading scenarios}

To investigate if the scenarios add value to the selection of ecosystem services by experts, we asked an additional expert group to compile a list in a similar way, but without having any knowledge of the scenarios. Fourteen experts were identified through a combination of focus group discussion and snowball sampling (Reed et al. 2009), of which eight participated. These experts have substantial experience of the case study area and are familiar with the concept of ecosystem services. The answers from these experts were gathered into one list that represents their collective view (Table A4.1 in Appendix 4), in total containing 15 different services. Please see Appendix 4 for a detailed description of how the list was compiled.

\section{Literature search}

Finally, we compiled a separate list of the ecosystem services most commonly included in published Southern African ecosystem services assessments carried out in agricultural landscapes. The list was developed using the ISI Web of Knowledge (complete search methods described in Appendix A5.1) and resulted in 10 papers (Appendix A5.2), including a total of 18 different ecosystem services that have been studied in Southern African agricultural areas (Table A5.1 in Appendix 5).

\section{Analysis}

We compared the similarity between all the ranked ecosystem services in the four lists, using the nonmetric Bray-Curtis dissimilarity index (Bray and Curtis 1957). This similarity measure is a modified Manhattan measurement in which the summed differences between the variables are standardized by the summed variables of the objects, i.e., identity, placement, and number of services in each list are taken into account. Low values (\%) indicate little similarity and high values indicate that there is a high similarity in ranking among lists.

Multiple ecosystem services assessments most commonly assess up to five services and rarely include much more than ten services (Seppelt et al. 2011). Therefore, we compared the ten highest ranked services in each list, dividing the services into provisioning, regulating, and cultural services, using the nonparametric Kruskal-Wallis ANOVA test. All tests were performed in Primer 6 (statistical software). In order to include the ranking of the service categories in each list as well, the summed score of services belonging to each category was divided with the total scores in each list separately. We considered water quantity and water quality to be both regulating and provisioning services, and biodiversity as both a regulating and a cultural service. Hence, the score in a list, for example, for biodiversity, was equally divided between regulating and cultural services in that list. If the tenth place in a list had more than one service with the same rank all of these were included.

\section{RESULTS}

When comparing similarity among the four lists we found that the literature list was the least similar compared to the other three lists (the two lists based on the scenarios and the list from experts not reading the scenarios) (Figure 3). The most similar lists were the two lists based on the scenarios. The list by the experts not reading scenarios only slightly differed from the two lists compiled by using the scenarios.

Fig. 3. The similarity (\%) among ecosystem services presented in the four lists based on a literature search, experts reading or not reading scenarios, and scenario stakeholders (see text for explanation). The resemblance was measured using the S17 Bray Curtis Index.

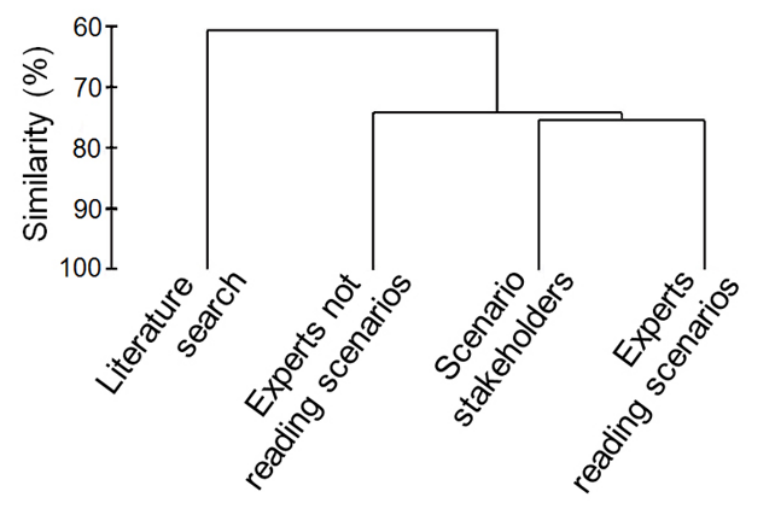

Figure 4 illustrates the comparison of the ecosystem services present in the four lists, in total containing 23 services. The literature list highlights services that are less prioritized or not present at all in the other three lists, such as other material, biofuel, flood control, disease control, and habitat provision. Some services, such as tourism, cultural identity, and carbon sequestration that have a relatively high ranking in the other lists have a low priority in the literature list. However, the lists also show many similarities. Twelve out of 23 services are present in all four lists. One service, crop production, occurs, not surprisingly, as one of the three highest ranked services in each of the four lists. Two services, biodiversity and water quantity, are ranked among the three highest prioritized services in three of the lists. Water quantity, crop production, and biodiversity, in that order, are the highest ranked when all percentages are added up in all four lists.

There was a statistically significant difference in the distribution of ecosystem service categories among the topten lists ( $d f=2, p=0.029)$ (Figure 5). Again, the literature list 
Fig. 4. The four lists of ranked ecosystem services. The value on the y-axes is the $\%$ of the total score for the service in that particular list.

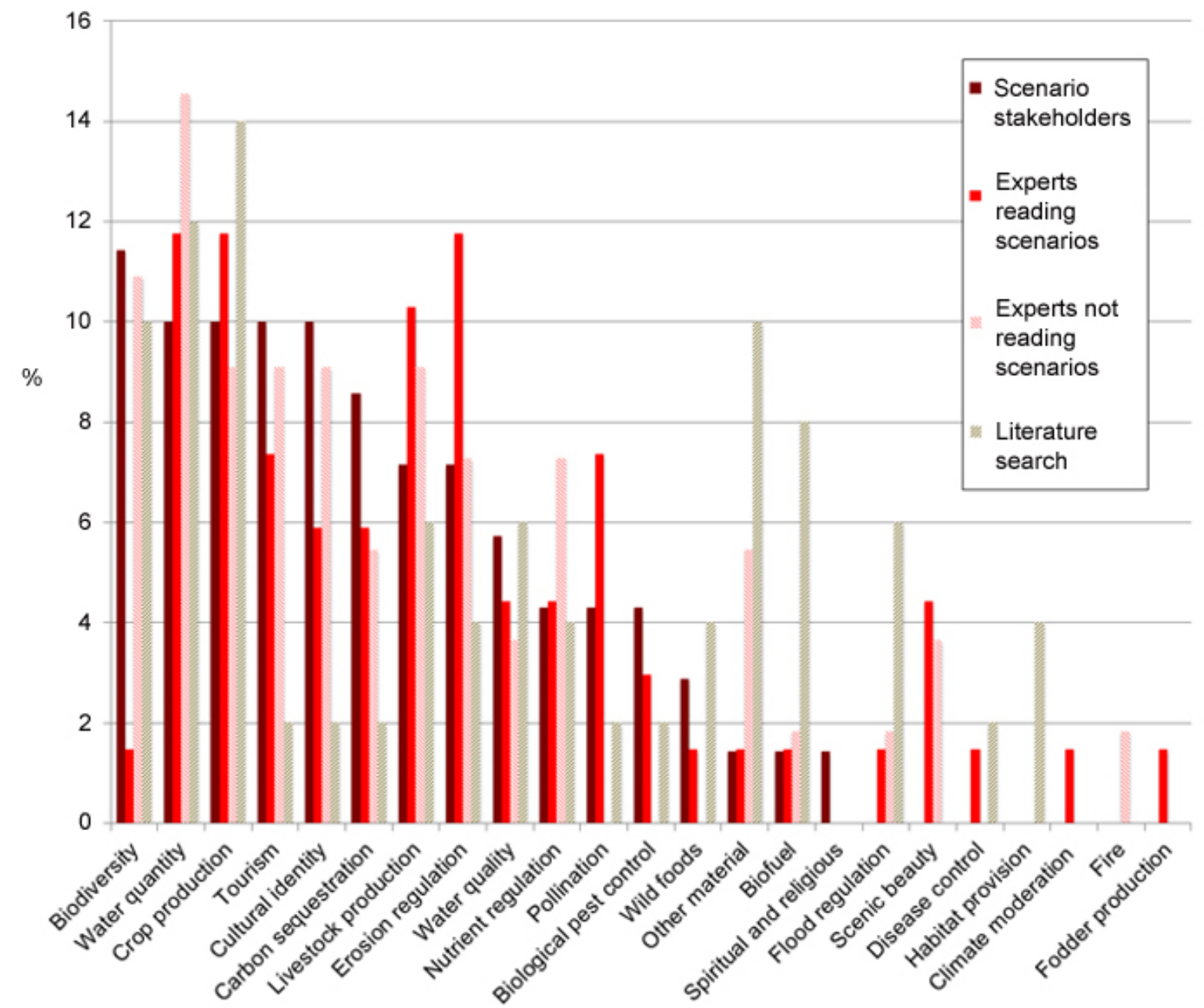

was most different from the other lists (Tukey post-hoc, $\mathrm{P}<0.05$ ), showing fewer cultural services in favor of provisioning services. Although no statistical difference is found, the lists developed by the scenario stakeholders and the list of experts not reading scenarios appear to prioritize cultural services higher than what is found in the list by external experts only reading the scenarios and the case study description. Experts not reading the scenarios have the most even distribution among categories in their top-ten list (Figure 5).

\section{DISCUSSION}

When comparing the four lists of suggested ecosystem services to assess in this region, the literature list was most dissimilar in terms of identity, ranking, and number of services compared to the other three lists. It is interesting that the other three lists are so similar. The two things that differ among these groups are the extent to which the people in the groups have experience of working and/or living in the region (both the scenario stakeholders and the experts not reading the scenarios had this experience, while the experts reading the scenarios did not), and the extent to which they were influenced by the scenarios (the scenario stakeholders developed them, and the external experts read them). One could argue that after reading the case study description and the three scenarios, the external group also had a certain knowledge of the site specifics of the region. The fact that all three lists were so similar may therefore mean that site-specific local knowledge, which they all shared to some degree, is more important than understanding how the landscape will change over time, which only two of them shared. 
Fig. 5. The distribution (\%) among the top-ten ranked ecosystem services categories (cultural, regulating, and provisioning services) in each list; a) scenario stakeholders, b) experts reading scenarios, c) experts not reading scenarios, and d) literature search. The summed score of the services in each category is presented as $\%$ of the total score in each list. We categorize water quantity and water quality as both a regulating and a provisioning service, and biodiversity as both a regulating and a cultural service, dividing the scores equally among the two categories.

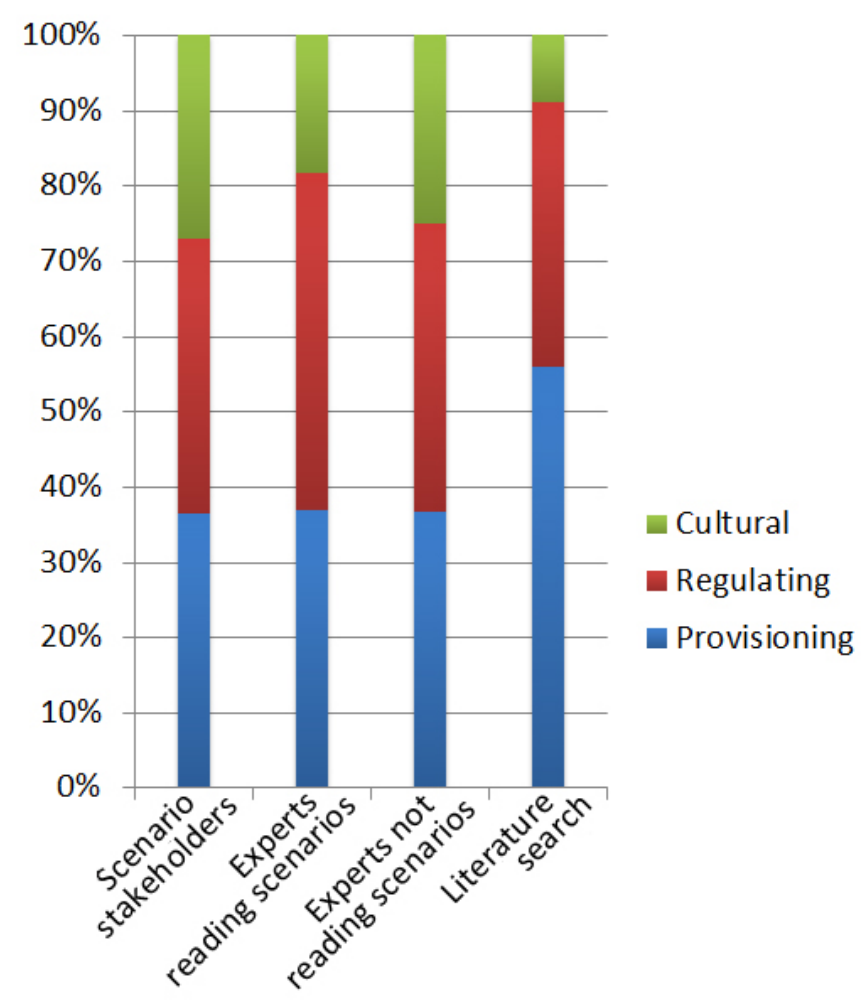

Another reason for the similarity could be that the scenarios were too cautious to generate a large difference between ecosystem services today and in the future. Scenario planning is a tool for exploring uncertainties and complexities in a changing world. The scenarios developed through this research were aimed to be plausible, but none of them deal with extreme change. This may have contributed to the fact that the lists developed by the scenario stakeholders and the experts reading the scenarios were very similar.

Although scenario exercises aim to capture future uncertainties, it must be highlighted that the general imagination of the future is limited and often primarily reflects current worldviews (Carpenter et al. 2006). This could also explain the fact that the three lists compiled based on the scenarios and/or knowledge of the study area were fairly similar.

It is perhaps not surprising that the literature top-ten services are dominated by provisioning services since the literature search specifically focused on agricultural landscapes. The other three lists prioritize regulating, provisioning, and cultural services almost equally. Even though cultural services are often recognized in ecosystem services assessments, they have been given relatively limited attention to this point (Chan et al. 2012, Daniel et al. 2012). This is also reflected in the literature top-ten list in this study, of which cultural services only constitute $6 \%$, compared to the other three lists that contain between $21 \%$ and $28 \%$ (Figure 5). The scenario stakeholders and the experts thus attribute higher importance to cultural services.

One service that was highly prioritized by scenario stakeholders, experts not reading the scenarios, and the literature search, but had a low ranking on the expert list, was biodiversity. One explanation is that biodiversity is not always considered an ecosystem service in itself (Mace et al. 2012). Some scholars argue that biodiversity should not be treated and viewed as an ecosystem service, because it underpins all ecosystem services generation (Mace et al. 2012). This could be one explanation as to why biodiversity was left out of the list compiled by the group of experts. We argue that biodiversity not only regulates ecosystem services generation, but can also be seen as a cultural ecosystem service because of the intrinsic value many people attribute to it. In addition, biodiversity conservation per se is a political goal in many international processes (Secretariat of the Convention on Biological Diversity 2005).

Participatory scenario planning definitely takes more time and resources than a "desk top" analysis of important services for a study region. Additionally, there might be a risk that scenario planning raises hopes among participants if the objectives and planned outcomes are not carefully communicated or completely understood. However, this scenario development process brought substantial additional benefits to our planned future ecosystem services assessment project in the Upper Thukela region. First, it proved to be a useful tool to learn about some of the major fears and expectations about the future among people in the area. Second, it explored key trends and uncertainties and identified major potential changes to people and to ecosystem services in the region over the next 20 years. The current project can now relate to these future uncertainties and changes, to avoid the risk of becoming constrained by a project vision that only applies in a status quo environment (Enfors et al. 2008). Scenario planning has helped us to understand how the project can develop in alternative plausible futures and how that relates to future services. It has also 
improved the understanding of events and processes that may either challenge the project or provide opportunities for it (cf. Bennett and Zurek 2006). Developing alternative scenarios, parallel to the project vision, encourages project participants to think about factors that might alter the expected development path, and to consider a number of interacting driving forces and how they are linked to ecosystem service generation through time. Finally, scenario planning can, by identifying opportunities and threats that might present themselves in the future, help a community push its development in a more desirable direction (Peterson 2007). While this is a long and challenging process, it certainly helped establish contacts between researchers and local stakeholders and provided a platform for sharing ideas and expectations, which might help future project efforts.

\section{CONCLUSIONS}

This study examined whether scenario development is a useful tool for selecting ecosystem services that should be included in an ecosystem services assessment of changing landscapes. We found no clear evidence that a different set of services was preferred when using scenario planning compared to when consulting experts with knowledge about the case study area. However, we found a clear difference when comparing scenario planning and expert opinion with what most commonly is found in the literature. In general, the scenario stakeholders and experts prioritize regulating, provisioning, and cultural services almost equally, while literature from agricultural landscapes prioritized provisioning services. We stress that scenario planning could be a useful tool to prioritize among the services to be assessed if you have little or no knowledge of the area, but the additional understanding of the study area gained through the scenario exercise is not very different from the understanding that experts gain from actively working in the area. Scenario development takes a lot of resources, and carrying out scenario planning solely for the purpose of identifying ecosystem services might be cost ineffective. However, through the scenario development process it is possible to establish a platform for discussion with local and regional stakeholders about the future in a region, which is very valuable for an ecosystem service project.

Responses to this article can be read online at: http://www.ecologyandsociety.org/issues/responses. $\mathrm{php} / 5494$

\section{Acknowledgments:}

We thank all the farmers of Potshini community, Bergville, and Winterton, workshop participants, and all additional stakeholders and experts for valuable input. We thank three anonymous reviewers for comments that helped improve the manuscript. The work was funded by The Swedish Research Council Formas, and Ebba och Sven Schwartz Stiftelse.

\section{LITERATURE CITED}

Alcamo, J., D. van Vuuren, C. Ringler, W. Cramer, T. Masui, J. Alder, and K. Schulze. 2005. Changes in nature's balance sheet: model-based estimates of future worldwide ecosystem services. Ecology and Society 10(2):19. [online] URL: http:// www.ecologyandsociety.org/vol10/iss2/art19/

Anderson, B. J., P. R. Armsworth, F. Eigenbrod, C. D. Thomas, S. Gillings, A. Heinemeyer, D. B. Roy, and K. J. Gaston. 2009. Spatial covariance between biodiversity and other ecosystem service priorities. Journal of Applied Ecology 46:888-896. http://dx.doi.org/10.1111/j.1365-2664.2009.01666. X

Bennett, E. M., S. R. Carpenter, G. D. Peterson, G. S. Cumming, M. Zurek, and P. Pingali. 2003. Why global scenarios need ecology. Frontiers in Ecology and the Environment 1(6):322-329.

Bennett, E. M., G. D. Peterson, and L. J. Gordon. 2009. Understanding relationships among multiple ecosystem services. Ecology Letters 12:1394-1404. http://dx.doi. org/10.1111/j.1461-0248.2009.01387.x

Bennett, E., and M. Zurek, editors. 2006. Field guide to the future: four ways for communities to think ahead. Center for International Forestry Research (CIFOR), Alternatives to Slash and Burn (ASB), World Agroforestry Center (ICRAF), Nairobi, Kenya.

Biggs, R., C. Raudsepp-Hearne, C. Atkinson-Palombo, E. Bohensky, E. Boyd, G. Cundill, H. Fox, S. Ingram, K. Kok, S. Spehar, M. Tengö, D. Timmer, and M. Zurek. 2007. Linking futures across scales: a dialog on multiscale scenarios. Ecology and Society 12(1):17. [online] URL: http://www. ecologyandsociety.org/vol12/iss1/art17/

Bohensky, E. L., B. Reyers, and A. S. van Jaarsveld. 2006. Future ecosystem services in a Southern African river basin: a scenario planning approach to uncertainty. Conservation Biology 20:1051-1061. http://dx.doi.org/10.1111/ j.1523-1739.2006.00475.x

Bray, J. R., and J. T. Curtis. 1957. An ordination of the upland forest communities of southern Wisconsin. Ecological Monographs 27:325-349. http://dx.doi.org/10.2307/1942268

Carpenter, S. R., E. M. Bennett, and G. D. Peterson. 2006. Editorial: special feature on scenarios for ecosystem services. Ecology and Society 11(2):32. [online] URL:http://www. ecologyandsociety.org/vol11/iss2/art32/

Carpenter, S. R., H. A. Mooney, J. Agard, D. Capistrano, R. S. DeFries, S. Díaz, T. Dietz, A. K. Duraiappah, A. OtengYeboah, H. M. Pereira, C. Perrings, W. V. Reid, J. Sarukhan, 
R. J. Scholes, and A. Whyte. 2009. Science for managing ecosystem services: beyond the Millennium Ecosystem Assessment. Proceedings of the National Academy of Sciences of the United States of America 106(5):1305-1312. http://dx. doi.org/10.1073/pnas.0808772106

Chan, K. M. A., A. D. Guerry, P. Balvanera, S. Klain, T. Satterfield, X. Basurto, A. Bostrom, R. Chuenpagdee, R. Gould, B. S. Halpern, N. Hannahs, J. Levine, B. Norton, M. Ruckelshaus, R. Russell, J. Tam, and U. Woodside. 2012. Where are the cultural and social in ecosystem services? A framework for constructive engagement. Bioscience 62 (8):744-756.

Cowling, R. M, B. Egoh, A. T. Knight, P. J. O'Farrell, B. Reyers, M. Rouget, D. J. Roux, A. Welz, and A. WilhelmRechman. 2008. An operational model for mainstreaming ecosystem services for implementation. Proceedings of the National Academy of Sciences of the United States of America 105(28):9483-9488. http://dx.doi.org/10.1073/pnas.0706559105

Cumming, G. S., J. Alcamo, O. Sala, R. Swart, E. M. Bennett, and M. Zurek. 2005. Are existing global scenarios consistent with ecological feedbacks? Ecosystems 8:143-152.

Daniel, T. C., A. Muhar, A. Arnberger, O. Aznar, J. W. Boyd, K. M. A. Chan, R. Costanza, T. Elmqvist, C. G. Flint, P. H. Gobster, A. Grêt-Regamey, R. Lave, S. Muhar, M. Penker, R. G. Ribe, T. Schauppenlehner, T. Sikor, I. Soloviy, M. Spierenburg, K. Taczanowska, J. Tame, and A. von der Dunk. 2012. Contributions of cultural services to the ecosystem services agenda. Proceedings of the National Academy of Sciences of the United States of America 109(23):8812-8819. http://dx.doi.org/10.1073/pnas.1114773109

de Groot, R. S., R. Alkemade, L. Braat, L. Hein, and L. Willemen. 2010. Challenges in integrating the concept of ecosystem services and values in landscape planning, management and decision making. Ecological Complexity 7:260-272. http://dx.doi.org/10.1016/j.ecocom.2009.10.006

Department of Water Affairs (DWA). 2011. The groundwater dictionary. Second edition. Department of Water Affairs, Republic of South Africa. [online] URL: http://www.dwaf. gov.za/Groundwater/GroundwaterDictionary.aspx

Enfors, E. I., L. J. Gordon, G. D. Peterson, and D. Bossio. 2008. Making investments in dryland development work: participatory scenario planning in the Makanya catchment, Tanzania. Ecology and Society 13(2):42. [online] URL: http:// www.ecologyandsociety.org/vol13/iss2/art42/

Fisher, B., R. K. Turner, N. D. Burgess, R. D. Swetnam, J. Green, R. E. Green, G. Kajembe, K. Kulindwa, S. L. Lewis, R. Marchant, A. R. Marshall, S. Madoffe, P. K. T. Munishi, S. Morse-Jones, S. Mwakalila, J. Paavola, R. Naidoo, T. Ricketts, M. Rouget, S. Willcock, S. White, and A. Balmford. 2011. Measuring, modeling and mapping ecosystem services in the Eastern Arc Mountains of Tanzania. Progress in Physical Geography 35(5):595-611. http://dx.doi. org/10.1177/0309133311422968

Francis, E. 2006. Poverty: causes, responses and consequences in rural South Africa. Chronic Poverty Research Centre Working Paper No. 60. Chronic Poverty Research Centre, London, UK. http://dx.doi.org/10.2139/ssrn.1753637

Goldstein, J. H., G. Caldarone, T. K. Duarte, D. Ennaanay, N. Hannahs, G. Mendoza, S. Polasky, S. Wolny, and G. C. Daily. 2012. Integrating ecosystem-service tradeoffs into land-use decisions. Proceedings of the National Academy of Sciences of the United States of America 109(19):7565-7570. http://dx. doi.org/10.1073/pnas.1201040109

Kane, M., and J. D. Erickson. 2007. Urban metabolism and payment for ecosystem services: history and policy analysis of the New York City water supply. Advances in the economics of environmental resources 7:307-328. http://dx.doi. org/10.1016/S1569-3740(07)07013-7

Kok, K., R. Biggs, and M. Zurek. 2007. Methods for developing multiscale participatory scenarios: insights from southern Africa and Europe. Ecology and Society 13(1):8. [online] URL: http://www.ecologyandsociety.org/vol12/iss1/ art81

Kühn, I., S. M. Bierman, W. Durka, and S. Klotz. 2006. Relating geographical variation in pollination types to environmental and spatial factors using novel statistical methods. New Phytologist 172:127-139. http://dx.doi. org/10.1111/j.1469-8137.2006.01811.x

Lavorel, S., K. Grigulis, P. Lamarque, M.-P. Colace, D. Garden, J. Girel, G. Pellet, and R. Douzet. 2011. Using plant functional traits to understand the landscape distribution of multiple ecosystem services. Journal of Ecology 99:135-147. http://dx.doi.org/10.1111/j.1365-2745.2010.01753.x

Lynch, S. D. 2004. Development of a raster database of annual, monthly and daily rainfall for southern Africa. WRC Report 1156/1/04. Water Research Commission, Pretoria, Republic of South Africa.

Mace, G. M., K. Norris, and A. H. Fitter. 2012. Biodiversity and ecosystem services: a multilayered relationship. Trends in Ecology and Evolution 27(1):19-26. http://dx.doi.org/10.1016/ j.tree.2011.08.006

Millennium Ecosystem Assessment (MA). 2005. Ecosystems and human well-being: desertification synthesis. World Resources Institute, Washington D. C., USA. [online] URL: http://www.millenniumassessment.org/en/Synthesis.aspx

Nelson, E., G. Mendoza, J. Regetz, S. Polasky, H. Tallis, D. R. Cameron, K. M. Chan, G. C. Daily, J. Goldstein, P. M. Kareiva, E. Lonsdorf, R. Naidoo, T. H. Ricketts, and M. R. Shaw. 2009. Modeling multiple ecosystem services, 
biodiversity conservation, commodity production, and tradeoffs at landscape scales. Frontiers in Ecology and the Environment 7:4-11. http://dx.doi.org/10.1890/080023

O'Farrell, P. J., B. Reyers, D. C. Le Maitre, S. J. Milton, B. Egoh, A. Maherry, C. Colvin, D. Atkinson, W. De Lange, J. N. Blignaut, and R. M. Cowling. 2010. Multi-functional landscapes in semi arid environments: implications for biodiversity and ecosystem services. Landscape Ecology 25:1231-1246. http://dx.doi.org/10.1007/s10980-010-9495-9

Parrott, L., and W. S. Meyer. 2012. Future landscapes: managing within complexity. Frontiers in Ecology 10 (7):382-389. http://dx.doi.org/10.1890/110082

Peterson, G. D. 2007. Using scenario planning to enable an adaptive co-management process in the Northern Highlands Lake District of Wisconsin. Pages 289-307 in F. Berkes, D. Armitage, and N. Doubleday, editors. Adaptive comanagement: collaboration, learning, and multi-level governance. University of British Columbia Press, Vancouver, Canada.

Peterson, G. D., T. D. Beard Jr., B. E. Beisner, E. M. Bennett, S. R. Carpenter, G. S. Cumming, C. L. Dent, and T. D. Havlicek. 2003a. Assessing future ecosystem services: a case study of the Northern Highlands Lake District, Wisconsin. Conservation Ecology 7(3):1. [online] URL: http://www. consecol.org/vol7/iss3/art1

Peterson, G. D., G. S. Cumming, and S. R. Carpenter. $2003 b$. Scenario planning: a tool for conservation in an uncertain world. Conservation Biology. 17:358-366.

Posthumus, H., J. R. Rouquette, J. Morris, D. J. G. Gowing, and T. M. Hess. 2010. A framework for the assessment of ecosystem goods and services; a case study on lowland floodplains in England. Ecological Economics 69:1510-1523. http://dx.doi.org/10.1016/j.ecolecon.2010.02.011

Raudsepp-Hearne, C., G. D. Peterson, and E. M. Bennett. 2010. Ecosystem service bundles for analyzing tradeoffs in diverse landscapes. Proceedings of the National Academy of Sciences of the United States of America. 107(11):5242-5247. http://dx.doi.org/10.1073/pnas.0907284107

Reed, M. S., A. Graves, N. Dandy, H. Posthumus, K. Hubacek, J. Morris, C. Prell, C. H. Quinn, and L. C. Stringer. 2009. Who's in and why? A typology of stakeholder analysis methods for natural resource management. Journal of Environmental Management 90:1933-1949. http://dx.doi. org/10.1016/j.jenvman.2009.01.001

Reyers, B., P. J. O'Farrell, R. M. Cowling, B. N. Egoh, D. C. Le Maitre, and J. H. J. Vlok. 2009. Ecosystem services, landcover change, and stakeholders: finding a sustainable foothold for a semiarid biodiversity hotspot. Ecology and Society 14 (1):38. [online] URL: http://www.ecologyandsociety.org/ vol14/iss $1 /$ art38/
Rogers, H. M., L. Glew, M. Honzák, and M. D. Hudson. 2010. Prioritizing key biodiversity areas in Madagascar by including data on human pressure and ecosystem services. Landscape and Urban Planning 96:48-56. http://dx.doi.org/10.1016/j. landurbplan.2010.02.002

Rounsevell, M. D. A., and M. J. Metzger. 2010. Developing qualitative scenario storylines for environmental change assessment. Wiley Interdisciplinary Reviews: Climate Change 1:606-619. http://dx.doi.org/10.1002/wcc.63

Secretariat of the Convention on Biological Diversity (CBD). 2005. Handbook of the Convention on Biological Diversity including its Cartagena Protocol on Biosafety. Third edition. The Secretariat of the Convention on Biological Diversity Montreal, Quebec, Canada.

Seppelt, R., C. F. Dormann, F. V. Eppink, S. Lautenbach, and S. Schmidt. 2011. A quantitative review of ecosystem service studies: approaches, shortcomings and the road ahead. Journal of Applied Ecology 48:630-636. http://dx.doi.org/10.1111/ j.1365-2664.2010.01952.x

Seppelt, R., B. Fath, B. Burkhard, J. L. Fisher, A. GrêtRegamey, S. Lautenbach, P. Pert, S. Hotes, J. Spangenberg, P. H. Verburg, and A. P. E. van Oudenhoven. 2012. Form follows function? Proposing a blueprint for ecosystem service assessments based on reviews and case studies. Ecological Indicators 21:145-154. http://dx.doi.org/10.1016/j. ecolind.2011.09.003

Smit, H. J., M. J. Metzger, and F. Ewert. 2008. Spatial distribution of grassland productivity and land use in Europe. Agricultural Systems 98:208-219. http://dx.doi.org/10.1016/j. agsy.2008.07.004

Statistics South Africa. 2009. Community survey 2007. Basic results: KwaZulu-Natal. Statistics South Africa, Pretoria, Republic of South Africa. [online] URL: www.statssa.gov.za/ Publications/Report-03-01-35/Report-03-01-352007.pdf

Thornton, A. 2009. Pastures of plenty?: Land rights and community-based agriculture in Peddie, a former homeland town in South Africa. Applied Geography 29:12-20. http://dx. doi.org/10.1016/j.apgeog.2008.06.001

Tottrup, C. 2004. Improving tropical forest mapping using multi-date Landsat TM data and pre-classification image smoothing. International Journal of Remote Sensing 25 (4):717-730. http://dx.doi.org/10.1080/01431160310001598926

Tress, B., and G. Tress. 2003. Scenario visualisation for participatory landscape planning - a study from Denmark. Landscape and Urban Planning 64:161-178. http://dx.doi. org/10.1016/S0169-2046(02)00219-0

van der Heijden, K. 2005. Scenarios: the art of strategic conversation. Second edition. John Wiley and Sons, Chichester, West Sussex, UK. 
van Wilgen, B. W., and W. J. De Lange. 2011. The costs and benefits of biological control of invasive alien plants in South Africa. African Entomology 19(2):504-514. http://dx.doi. org/10.4001/003.019.0228

Walker, B., S. Carpenter, J. Anderies, N. Abel, G. Cumming, M. Janssen, L. Lebel, J. Norberg, G. D. Peterson, and R. Pritchard. 2002. Resilience management in social-ecological systems: a working hypothesis for a participatory approach. Conservation Ecology 6(1):14. [online] URL: http://www. consecol.org/vol6/iss1/art14

Wang, G., Q. Fang, L. Zhang, W. Chen, Z. Chen, and H. Hong. 2010. Valuing the effects of hydropower development on watershed ecosystem services: case studies in the Jiulong river watershed, Fujian province, China. Estuarine, Coastal and Shelf Science 86:363-368. http://dx.doi.org/10.1016/j. ecss.2009.03.022

Wendland, K. J., M. Honzák, R. Portela, B. Vitale, S. Rubinoff, J. Randrianarisoa. 2010. Targeting and implementing payments for ecosystem services: opportunities for bundling biodiversity conservation with carbon and water services in Madagascar. Ecological Economics 69:2093-2107. http://dx. doi.org/10.1016/j.ecolecon.2009.01.002

Whitfield, S., and M. S. Reed. 2012. Participatory environmental assessment in drylands: introducing a new approach. Journal of Arid Environments 77:1-10. http://dx. doi.org/10.1016/j.jaridenv.2011.09.015

Willaarts, B., M. Volk, and P. A. Aguilera. 2012. Assessing the ecosystem services supplied by freshwater flows in Mediterranean agroecosystems. Agricultural Water Management 105:21-31. http://dx.doi.org/10.1016/j.agwat.2011.12.019

Wollenberg, E., D. Edmunds, and L. Buck. 2000a. Anticipating change: scenarios as a tool for adaptive forest management. A guide. Center for International Forestry Research (CIFOR), Bogor, Indonesia.

Wollenberg, E., D. Edmunds, and L. Buck. 2000b. Using scenarios to make decisions about the future: anticipatory learning for the adaptive co-management of community forests. Landscape and Urban Planning 47:65-77. 


\section{APPENDIX 1 \\ Drivers of change}

Table A1.1. A summary of interviews with local resource users: smallholder subsistence farmers, large-scale commercial farmers and representatives for nature reserves. The table presents the drivers of change that were identified by the users and ranked as the most important and most uncertain. The nature reserve representatives did not separate the important and uncertain drivers, but identified them as the most important and/or uncertain.

\begin{tabular}{|c|c|c|}
\hline User Group & \multicolumn{2}{|c|}{ Drivers } \\
\hline $\begin{array}{c}\text { (number of groups/number } \\
\text { of informants) }\end{array}$ & Most important & Most uncertain \\
\hline $\begin{array}{c}\text { Small-scale } \\
\text { subsistence agriculture } \\
(3 / 11)\end{array}$ & $\begin{array}{c}\text { Agricultural productivity } \\
\text { Health } \\
\text { Education }\end{array}$ & $\begin{array}{c}\text { Weather } \\
\text { Local Governance } \\
\text { Infrastructure }\end{array}$ \\
\hline $\begin{array}{c}\text { Large-scale } \\
\text { commercial agriculture } \\
(3 / 9)\end{array}$ & $\begin{array}{c}\text { Welitical stability } \\
\text { Security }\end{array}$ & $\begin{array}{c}\text { Land reform } \\
\text { Economy } \\
\text { Weather }\end{array}$ \\
\hline $\begin{array}{c}\text { Nature reserves } \\
(2 / 2)\end{array}$ & \multicolumn{2}{|c|}{$\begin{array}{c}\text { Sustainable livelihoods } \\
\end{array}$} \\
\hline
\end{tabular}

Table A1.2. The starting points of the scenarios, deciding the development trajectory for the scenarios. Each of the key drivers are described, namely, in which direction they develop, or they are stated as unchanged or undefined in the three scenarios. The starting points formed the base for drafting the scenarios.

\begin{tabular}{|l|c|c|c|}
\hline \multicolumn{1}{|c|}{ Key driver } & $\begin{array}{c}\text { EOUAL } \\
\text { ENVIRONMENT }\end{array}$ & $\begin{array}{c}\text { DIVERGING } \\
\text { CLIMATE }\end{array}$ & $\begin{array}{c}\text { ADAPTIVE } \\
\text { COLLABORATION }\end{array}$ \\
\hline Security & Unchanged & Decreased & Improved \\
\hline $\begin{array}{l}\text { Enforcement of laws } \\
\text { and agreements }\end{array}$ & Functioning & Non-functioning & Functioning \\
\hline Investments & $\begin{array}{l}\text { Government } \\
\text { (development) }\end{array}$ & Market & Little \\
\hline Entrepreneurship & Weak/passive & Individual & Collaborative \\
\hline Climate & Undefined & Better & Worse \\
\hline
\end{tabular}




\section{APPENDIX 2}

Scenario contrasts

Table A2.1. The main differences between the three scenarios in terms of drivers and themes that develop in different ways and drive the scenarios into contrasting development trajectories.

\begin{tabular}{|c|c|c|c|c|}
\hline \multicolumn{2}{|c|}{ THEMES/DRIVERS } & EQUAL ENVIRONMENT & DIVERGING CLIMATE & ADAPTIVE COLLABORATION \\
\hline CLIMATE & Climate & Undefined & Better conditions for agriculture & $\begin{array}{l}\text { Worse conditions } \\
\text { Extreme weather events }\end{array}$ \\
\hline \multirow{5}{*}{$\begin{array}{l}\text { GOVERNANCE/ } \\
\text { INSTITUTIONS }\end{array}$} & $\begin{array}{l}\text { Development } \\
\text { investments }\end{array}$ & $\begin{array}{l}\text { Substantial investments for rural } \\
\text { development by government }\end{array}$ & $\begin{array}{l}\text { Private investments where } \\
\text { profitable }\end{array}$ & $\begin{array}{c}\text { Few outside investments } \\
\text { Local NGO's drive some development }\end{array}$ \\
\hline & $\begin{array}{l}\text { Entrepreneurship/ } \\
\text { local initiatives }\end{array}$ & Weak entrepreneurial spirit & Individual entrepreneurs dominant & Collaborative entrepreneurship \\
\hline & $\begin{array}{l}\text { Enforcement of laws } \\
\text { and agreements }\end{array}$ & $\begin{array}{l}\text { Strong local and national authorities } \\
\text { Low corruption }\end{array}$ & $\begin{array}{l}\text { Corrupt and weak } \\
\text { national government }\end{array}$ & $\begin{array}{c}\text { Strong local and } \\
\text { traditional authorities } \\
\text { Weak national government }\end{array}$ \\
\hline & Land redistribution & $\begin{array}{l}\text { Land reform gives } \\
\text { smallholders land access }\end{array}$ & Slow process of land reform & Land claims under slow process \\
\hline & $\begin{array}{l}\text { Biodiversity } \\
\text { conservation }\end{array}$ & $\begin{array}{l}\text { New agri-environmental } \\
\text { schemes involve farmers }\end{array}$ & National and global carbon offset & No general development/change \\
\hline \multirow{5}{*}{$\begin{array}{l}\text { SOCIAL } \\
\text { OUTCOMES }\end{array}$} & $\begin{array}{l}\text { Income equality and } \\
\text { poverty }\end{array}$ & Increased income equality & Increased income inequality & $\begin{array}{l}\text { Inequalities remain } \\
\text { Poverty traps }\end{array}$ \\
\hline & Urbanization & $\begin{array}{l}\text { Rural development slow } \\
\text { down urbanization }\end{array}$ & More urbanization & More urbanization \\
\hline & Infrastructure & $\begin{array}{l}\text { Improved infrastructure } \\
\text { in rural countryside } \\
\text { Service delivery } \\
\end{array}$ & $\begin{array}{l}\text { Unequal development } \\
\text { of infrastructure }\end{array}$ & $\begin{array}{c}\text { Poor development } \\
\text { Local organizations } \\
\text { maintain minimal level }\end{array}$ \\
\hline & Security & Crime levels improved & Increased crime & No significant change \\
\hline & Tourism & $\begin{array}{l}\text { Increased tourism and } \\
\text { improved tourist routes }\end{array}$ & $\begin{array}{l}\text { Increased up-market } \\
\text { secure tourism }\end{array}$ & $\begin{array}{l}\text { Increased tourism on } \\
\text { rural countryside }\end{array}$ \\
\hline \multirow{4}{*}{$\begin{array}{l}\text { AGRICULTURAL } \\
\text { OUTCOMES }\end{array}$} & $\begin{array}{l}\text { Commercial: } \\
\text { crop production }\end{array}$ & $\begin{array}{c}\text { Slightly lower productivity } \\
\text { High input costs } \\
\text { Strict water and GMO regulations }\end{array}$ & $\begin{array}{l}\text { Increased crop productivity } \\
\text { Farmers adapt to } \\
\text { market dynamics }\end{array}$ & $\begin{array}{l}\text { Productivity unreliable but irrigation } \\
\text { buffer somewhat }\end{array}$ \\
\hline & $\begin{array}{l}\text { Commercial: } \\
\text { grazing lands }\end{array}$ & $\begin{array}{l}\text { Generally well managed } \\
\text { grazing lands }\end{array}$ & $\begin{array}{l}\text { Generally well managed } \\
\text { grazing lands }\end{array}$ & $\begin{array}{l}\text { Collective efforts for more } \\
\text { challenging grazing management }\end{array}$ \\
\hline & $\begin{array}{l}\text { Small-holder: } \\
\text { crop production }\end{array}$ & $\begin{array}{l}\text { Productivity levels } \\
\text { increased significantly }\end{array}$ & $\begin{array}{l}\text { Some farmers improve productivity } \\
\text { while most struggle }\end{array}$ & $\begin{array}{l}\text { Poor production } \\
\text { Collaboration give effects }\end{array}$ \\
\hline & $\begin{array}{l}\text { Small-holder: } \\
\text { grazing lands }\end{array}$ & $\begin{array}{l}\text { Lower stocking rates and improved } \\
\text { management strategies }\end{array}$ & $\begin{array}{l}\text { Grazing driven higher } \\
\text { up in marginal lands }\end{array}$ & $\begin{array}{c}\text { Co-management improved degraded } \\
\text { grazing lands }\end{array}$ \\
\hline
\end{tabular}




\section{EQUAL ENVIRONMENT - YEAR 2030}

\section{Government committed to environmental rural development}

Regional and national leaders realized in the early 2010s that the long-term foundation of South Africa's economic growth is reliant on the diversity of natural and social capital in the "Rainbow Nation". In 2015 they started a nation-wide campaign under the slogan 'Sustainable South Africa through Rural Investments for Poverty allEviation' (SA-RIPE), showing their devotion to sustain the substantial natural resource base, by investing in the majority of the population living in rural areas. Over the past 15 years, there have therefore been massive investments in rural development in South Africa, including investments in agriculture, infrastructure (e.g. roads, internet and mobile networks), health care, water and sanitation systems and education. This has resulted in poverty alleviation and a growing middle-class, slightly reducing the gap between rich and poor.

Corruption at all levels in society has successfully been decreased over the past years. Consequently, in the year 2030, people in the Upper Thukela region generally have a large trust in, and respect for, decisions made by local, as well as national, governments. However, petty crime conducted by smaller groups or individuals, is still an issue influencing people's daily life negatively.

Many people take advantage of opportunities that the improved infrastructure provides. However, there is also a general perception that the substantial hand-outs and subsidies from the government have made people passive and their entrepreneurial and business spirit is weakened.

\section{HIGHER COSTS FOR COMMERCIAL FARMERS}

Agriculture is still the most important income source and occupation for the population in the Upper Thukela region. The situation is, however, quite challenging for the commercial farmers in the area. The regulations on the use of chemicals and GMO's have led to increased input costs and slightly reduced crop yields for commercial farmers. They are also negatively affected by higher tax-rates. Water use for irrigation is strictly controlled and the enforcement of the water laws has improved since the early 2010's. Water charges are high, as a measure to secure the country's long-term water supply, and increased electricity costs make irrigation equipment prohibitively expensive to run. Although small, there is a clear trend of commercial farmers selling their lands to neighboring farms, or to land claimants, as they turn to various kinds of businesses and employment, such as contracting of machines, consulting, mentoring of emerging farmers and running factories for food processing and packaging.

\section{AGRICULTURAL SMALL-HOLDER BOOM SLOWS DOWN URBANIZATION}

While some of the commercial farmers are struggling, small-holder farmers have increased their shares in the agricultural market throughout the country, in turn contributing more to the country's tax returns. Initially free or subsidized input products such as seeds, fertilizers and soil amendments, as well as mechanized support for planting and har- vesting, have improved the productivity of the small-holder farms. The government's commitment to improving infrastructure and agricultural education in rural communities has slowed down the movement from rural to urban areas significantly, although higher education and better-paid jobs still attract some people to move to cities, for at least a period of their lives.

\section{HEALTHIER GRASSLANDS AND HIGHER BIODIVERSITY}

There have been clear environmental benefits of the SA-RIPE campaign. South Africa has, for example, become one of the world's leading countries when it comes to governing the use of chemicals and GMO crops. Despite substantial development and economic growth, the protection of national reserves has remained strong in these rural areas. A zoning system has been developed around the Drakenberg parks in the Upper Thukela, where communities living close to parks are involved in maintaining biodiversity and ecosystem values on their lands. There have also been many new governmental incentives, such as "payment for" and "working for" ecosystem services programs, creating financial incentives, and jobs, in order to manage land according to the country's new biodiversity conservation agenda.

This has improved grassland management through more regulated livestock keeping and fire management practices for both private and communal grazing lands, which has led to improved grasslands quality, where soil erosion has slowed down, resulting in better nutrient status, higher grass productivity, better quality water flows and higher carbon sequestration rates. Biodiversity loss in grasslands has slowed down and some grasslands are becoming richer in species diversity.

Many commercial, as well as small-scale, farmers in the Upper Thukela region have committed to the authorities' new agri-environmental scheme to secure biodiversity within and outside protected areas in the Drakensberg. This commitment involves reducing and controlling chemical use, creating buffer zones along water bodies, as well as providing natural habitats for pollination and pest controlling species adjacent to fields.

\section{...ATTRACTS TOURISTS}

The attractive nature of the area, together with upgraded tourist routes and tourism infrastructure, has led to a tourist boom in the region, mainly through international tourists, but also from within South Africa. This has the potential to create opportunities for both commercial and small-holder farmers to increase their income, but the interest in being involved in businesses outside agriculture is somewhat limited. Some commercial farmers, and a few smallholder farmers, have developed upmarket Bed \& Breakfast establishments and other accommodation on their farms as an additional income source. $: \bullet:$

\section{"This has improved grassland management through more regulated livestock keeping and fire management practices for both private and communal grazing lands."}


The Upper Thukela region is one of the areas in South Africa that has benefited from global climate change. Higher rainfall and warmer winters have increased agricultural production and the region has become a significant supplier of agricultural goods to other parts of South Africa that have been detrimentally affected by climate change. This has led private national and international companies to invest in this profitable region. Most of the investments have gone to private, large-scale commercial landholders. The government is, however, being criticized by a large majority of the population for taking little responsibility of the country's development. Thus, private companies have over the past two decades carried out most of the investments to improve infrastructure, such as roads and communication technologies. General investments in health care and education have been lacking. There are clearly some people who are better off in 2030 than in 2010 , but the huge inequalities in access to basic infrastructure, hospitals, water and sanitation, still persist.

Corruption among governmental officials and the police force is a significant problem, and political instability and weak enforcement of laws has created tension throughout the country, resulting in high crime levels.

COMMERCIAL FARMERS GO GENETIC OR ORGANIC Commercial farmers benefit from improved weather conditions and investments in general. Many farmers have also developed their adaptability and improved the capacity to respond quickly to fluctuating demands through investments in more flexible agricultural infrastructure, as well as more diverse cropping systems. There are two simultaneous trends among the commercial largescale farmers, leading to diversification of the produce coming from the Upper Thukela region. The dominant trend is one of increasingly high-tech and high-input crops (e.g. high levels of genetically-modified crops, fertilizers and pesticides), including biofuels. The other trend among a signifi cant number of the commercial far-

mers is in response to a raised global demand for ethical and organic trade: the creation of the local niche market association "Drakensberg Sustainably Produced Agricultural Products".

The rise in organic produce shows an interesting mental shift from the early 2000's when there was a general skepticism towards chemical-free agriculture. This shift came after a success case in 2013, where a large food production chain, WALLEES, initiated a successcollaboration with one of the commercial farmers, who tested new ways of high-diversity organic farming. This project also started a training program for smallholder farmers surrounding the commercial farmer's property, developing into a unique collaboration among small-holders and large-scale farmers. The WALLEES organic farming training camps have led to substantially higher yields among participating farmers. Mechanisms to facilitate the export of agricultural goods have also improved, including new processing factories that have started taking in produce from both commercial and small-holder farmers in the region.

\section{SUCCESSES AND FAILURES FOR SMALL-HOLDER FARMERS}

Despite a more favorable climate, there are many small-holder farmers who still struggle with low agricultural productivity, due to low investments in agricultural inputs, knowledge and technologies. Income levels in the rural communities are generally low and unreliable, and there is large migration from the region. Many people move to cities, take sporadic and seasonal employment, and relocate, to follow shifting commerce and businesses. However, the farmers that have managed to secure improved yields, have become quite successful and have extended their lands by taking over fields from migrating neighbors. This means that the average land holding for farmers in the area has grown, while the number of farmers has declined. The small, but relatively influential, group of successful small-scale farmers has become more agriculturally commercialized and is competing on the local market. These families generally have a higher level of education and a higher income.

\section{GRASSLAND AND BIODIVERSITY CONSERVATION SECURE BUT THREATENED}

National and global companies and individuals have taken increased responsibility for their greenhouse gas emissions, by making compensation payments through carbon offset programs. This has become a new source of funding for the protection and establishment of nature reserves in the region and has generally improved the protection of the biodiversity rich grasslands. In a few places, these carbon-offset funds are also used to create jobs for some local communities in the area, especially the ones located higher up in the catchments and adjacent to the protected areas. Soil erosion and water flows in these grazing lands are being managed through practices taught by researchers and practitioners from the nature reserves and carried out by community members. In the places where the program is run, the results are satisfactory. However, keeping livestock has also become more risky because of stock theft. The risk of stock theft, and the increased trade of cannabis, have driven livestock grazing higher up in the mountains, increasing erosion and threatening biodiversity in and outside national parks and nature reserves. It has also resulted in increased grazing closer to the villages, where high cattle numbers have accelerated erosion and land degradation, while some of the grazing lands are abandoned.

\section{FENCED-IN TOURISM}

Tourists are still attracted by the beauty of the national parks and nature reserves in the region and visitors are steadily increasing. The high crime level, however, means that the tourism is concentrated in fenced-off places with high security, hence very few of the local inhabitants can benefit from the increased number of visitors. : $\bullet$ : TERVIEWS AND WORKSHOPS WITH STAKEHOLDERS IN UPPER THUKELA, KWAZULU-NATAL 


\section{ADAPTIVE COLLABORATION - YEAR 2030}

\section{Farmers join forces to adapt to climate change and reverse land degradation}

\section{"The collaborative spirit, together with increased engagement of local leaders, has also led to increased respect for laws and agreements."}

\section{COLLABORATIVE FORCES CHANGED NEGATIVE TRENDS}

The Upper Thukela has during the past 20 years suffered from several extreme weather events that have had huge influence on agricultural production. Frequent floods, long periods of droughts, lower winter temperatures and late frosts have caused repeated damages to both crops and livestock. The economically weak and largely corrupt national government has not been capable to fund the recovery of economic losses caused by these weather events. The local government lacks the ability and money to invest in development of the rural communities in the area and only very minimal efforts are carried out to maintain infrastructure and basic social services, such as schools and health care. Many years of crises and a low trust in the government has, however, brought together other forces to handle the difficulties and uncertainties of the society. National and international NGO's play an increasing role in the development and capacity-building among communities and the less wealthy part of the population. For example, XING, an international IT-company based in China, has made large investments in communication infrastructure, and has provided schools with Internet and e-learning tools. This has opened up some work opportunities for the younger generation in e.g. web design and web trade.

The collaborative spirit, together with increased engagement of local leaders, has also led to an increased respect for laws and agreements. Levels of criminality are kept stable in the communities, but overall in the society, crime remains a big problem. Family values and religion tend to grow stronger.

\section{COMMERCIAL FARMERS MORE RESILIENT TO WEATHER FLUCTUATIONS}

The commercial farmers are generally more resilient than the smallholder farmers to climate fluctuation, since they have access to largescale irrigation systems and their grazing lands are healthier, with better management. Nevertheless, production has been very unreliable over the last 20 years. While farming is still profitable for many, there is a growing number of the farmers that give up and move to sub-urban settlements, overseas, or find alternative income sources and businesses. Collaboration and business partnership between commercial and small-holder farmers have become more noticeable, and some commercial farmers are involved with capacity-building and mentor programs in small-holder communities.

\section{LOCAL INVOLVEMENT HELPS IMPROVING POVERTY} AMONG SMALL-HOLDER FARMERS

The poor rural communities are the most vulnerable to the more variable and unfavorable climate. Although agriculture is still the most important livelihood for small-holder families, other income sources, such as handicrafts, tourism, teaching, nursing, seasonal commercial farm work and involvement with local organizations, have become increasingly important. Lack of job opportunities, insufficient social grants and low agricultural production mean that a large part of the population remains poor. Some people abandon agriculture as an oc- cupation and move to cities and towns. To a large extent, most families rely on remittances from their migrated family members.

This tough situation has forced new collaboration among community members. Through common investment in supplementary irrigation systems and machines, and by cultivating larger fields together, some people have managed to increase the productivity of their lands. Cooperatives have emerged and community saving funds have become more important for many community members.

NGO's have supported establishment of gardens to the communal farmlands, integrating trees, flowers and vegetables, which has lead to increased food security and species richness of flora and fauna. Strong efforts made by NGO's and local organizations, with a high participation of community members, have led to raised awareness among the population in the rural communities regarding sustainable farming and land management, where local traditional knowledge is successfully integrated with modern knowledge.

\section{LATE, BUT IMPORTANT, RECOVERY OF DEGRA- DED GRASSLANDS}

Cold winters, droughts and unusually dry springs during the years 2014 - 2018 had severe consequences for the livestock keepers, as many of the animals died. However, the rapid decline in grazing pressure has had a positive effect on recovery from erosion. Grazing management has become an important issue on the local agenda and some communities are successfully involved with payment for ecosystem services programs, where organizations are being paid by governmental and private funds to manage ecosystem services, such as water and soil erosion regulation. Locally constituted committees are being trained to run and monitor restoration and maintenance of degraded grasslands and gullies. The payment for the work is not always sufficient, nor efficiently handled, by authorities, due to corruption and the lack of government support, but the direct benefits of the work by the communities are so obvious that the program is nevertheless being continued and the commitment is high among the community members. The commercial cattle holders have also made collective efforts to adapt their grazing management as a response to the variable weather, with positive results for most farmers.

RURAL HOMESTAYS ATTRACT WORLD-TRAVELLERS Tourism has become an increased source of income for many families in the region. International and national visitors travel mainly to the national parks and nature reserves, although more and more tourists are interested in visiting rural communities and the agricultural countryside. Reduced crime rates resulting from increased community involvement and loyalty, as well as land availability, have opened up opportunities for both large- and small-scale farmers to build B\&B's in the rural communities and attract backpacker tourists with their 'traditional African homestays' in flourishing gardens. : $\bullet$

WRITTEN BY REBECKA MALINGA, LINE GORDON AND REGINA LINDBORG, BASED ON INTERVIEWS AND WORKSHOPS WITH STAKEHOLDERS IN UPPER THUKELA, KWAZULU-NATAL 


\begin{abstract}
APPENDIX 4
Lists of ecosystem services by experts
\end{abstract}

\title{
A4.1 Expert survey method used
}

The experts who participated in the survey received the following instructions:

Experts reading the scenarios

After reading through the attached description of the case study area, the three scenarios and the table of scenario contrasts, we would like to know what You think are the 5-10 most relevant ecosystem services to assess in our case study region. Write only one list, that considers the Upper Thukela region under the three different scenarios (i.e. don't write one sheet for each scenario). Don't be constrained by what services you perceive would be impossible or difficult to assess due to data availability, time or resources.

Experts not reading the scenarios

After reading through the attached description of the case study area, we would like to know what You think are the 5-10 most relevant ecosystem services to assess in our case study region. Don't be constrained by what services you perceive would be impossible or difficult to assess due to data availability, time or resources.

The experts filled out a form where they stated the services, an optional definition of the service, and a motivation to their choice of each service. The answers from the experts were compiled in to two lists, experts reading the scenarios and experts not reading the scenarios, respectively. First, some of the ecosystem services mentioned by the experts were renamed or grouped for consistency. For example, we used the broad category of water quantity for more specific processes mentioned such as water infiltration, or runoff. The services were then listed and got a score for each expert mentioning that service, hence the lists consists of the total number of services mentioned and ranked according to scores (Table A4.1). The experts reading the scenarios resulted in 20 different services and the experts not reading the scenarios mentioned in total 15 services (Table A4.1).

Table A4.1. Lists of ecosystem services compiled by experts. Total score is the number of experts who mentioned that service in the survey.

\begin{tabular}{llll} 
Experts reading scenarios & Total score & Experts not reading scenarios & Total score \\
\hline Crop production & 8 & Water quantity & 8 \\
Erosion regulation & 8 & Biodiversity & 6 \\
Water quantity & 8 & Crop production & 5 \\
Livestock production & 7 & Cultural identity & 5 \\
Pollination & 5 & Livestock production & 5 \\
Tourism & 5 & Tourism & 5 \\
Carbon sequestration & 4 & Erosion regulation & 4 \\
Cultural identity & 4 & Nutrient regulation & 4 \\
Nutrient regulation & 3 & Carbon sequestration & 3 \\
Scenic beauty & 3 & Other materials & 3
\end{tabular}


Water quality

Biological pest control

Biodiversity

Biofuels

Climate moderation

Disease control

Flood control

Fodder production

Other material

Wild foods
Scenic beauty

2

Water quality

Biofuel

Fire

Flood regulation
2

1

1

1 


\section{APPENDIX 5}

List of ecosystem services from literature

\section{A5.1 ISI Web of Knowledge data used}

To develop this list we searched the Web of Knowledge (ISI), using the words "ecosystem service*" OR "ecosystem goods and services" OR "environmental services" OR "ecological services") AND (agricultur* OR farm*) AND ("South Africa" OR "Southern Africa" OR "South African" OR "Southern African" OR Botswana* or Namibia* or Lesotho* or Swaziland*. In total, 62 papers (as per date October 18, 2012) were found, of which 52 papers were excluded, using the following three criteria: the analysis has to $i$ ) be performed within the ecosystem service frame work, ii) have a connection to specific agricultural area/s in the Southern African countries, thus excluding conceptual papers, and iii) include more than one service. Within the remaining ten papers we found a total of 18 different ecosystem services (Table A5.1).

To compile the list of services extracted from the literature search we listed all services mentioned in the ten papers. Some of the services were renamed or grouped for consistency. For example, we used the broad category of water quantity for more specific processes such as water infiltration or runoff. The services got a score for each paper that assessed that service, hence the list consists of the total number of services assessed in the ten papers and ranked according to scores (Table A5.1).

Table A5.1. List of ecosystem services compiled through literature and ranked according to number of papers that assessed each service (score).

\begin{tabular}{ll} 
Literature search & Total score \\
\hline Crop production & 7 \\
Water quantity & 6 \\
Biodiversity & 5 \\
Other material & 5 \\
Biofuel & 4 \\
Flood regulation & 3 \\
Livestock production & 3 \\
Water quality & 3 \\
Erosion regulation & 2 \\
Habitat provision & 2 \\
Nutrient regulation & 2 \\
Wild foods & 2 \\
Biological pest control & 1 \\
Carbon sequestration & 1 \\
Cultural identity & 1 \\
Disease control & 1 \\
Pollination & 1 \\
Tourism & 1
\end{tabular}




\section{A5.2 List of papers}

Child, M. F., G. S. Cumming, and, T. Amano. 2009. Assessing the broad-scale impact of agriculturally transformed and protected area landscapes on avian taxonomic and functional richness. Biological Conservation 142:2593-2601.

van Jaarsveld, A. S., R. Biggs, R. J. Scholes, E. Bohensky, B. Reyers, T. Lynam, C. Musvoto, and, C. Fabricius. 2005. Measuring conditions and trends in ecosystem services at multiple scales: the Southern African Millennium Ecosystem Assessment (SAfMA) experience. Philosophical Transactions of The Royal Society B 360:425-441.

Jogo, W., and, R. Hassan. 2010. Balancing the use of wetlands for economic well-being and ecological security: The case of the Limpopo wetland in southern Africa. Ecological Economics 69:1569-1579.

Lankford, B., C. Pringle, C. Dickens, F. Lewis, M. Mander, V. Chhotray, M. Goulden, Z. Nxele, and, L. Quayle. 2011. Hydrological modelling of water allocation, ecosystem services and poverty alleviation in the Pongola floodplain, South Africa. Journal of Environmental Planning and Management 54(9):1237-1260.

Mc Cartney, M., S. Morardet, L-M. Rebelo, C. M. Finlayson, and, M. Masiyandima. 2012. A study of wetland hydrology and ecosystem service provision: GaMampa wetland, South Africa. Hydrological Sciences Journal 56(8):1452-1466.

O'Farrell, P. J., J. S. Donaldson, and, M. T. Hoffman. 2009. Local benefits of retaining natural vegetation for soil retention and hydrological services. South African Journal of Botany 75:573-583.

O'Farrell, P. J., J. S. Donaldson, and, M. T. Hoffman. 2007. The influence of ecosystem goods and services on livestock management practices on the Bokkeveld plateau, South Africa. Agriculture Ecosystems and Environment 122:312-324.

Rockström, J., C. Folke, L. Gordon, N. Hatibu, G. Jewitt, F. Penning de Vries, F. Rwehumbiza, H. Sally, H. Savenije, and, R. Schulze. 2004. A watershed approach to upgrade rainfed agriculture in water scarce regions through Water System Innovations: an integrated research initiative on water for food and rural livelihoods in balance with ecosystem functions. Physics and Chemistry of the Earth 29:1109-1118.

Sengo, D. J., A. Kachapila, P. van der Zaag, M. Mul, and, S. Nkomo. 2005. Valuing environmental water pulses into the Incomati estuary: Key to achieving equitable and sustainable utilization of transboundary waters. Physics and Chemistry of the Earth 30:648-657.

Walters, D. J. J., D. C. Kotze, and, T. G. O'Connor. 2006. Impact of land use on vegetation composition, diversity, and selected soil properties of wetlands in the southern Drakensberg mountains, South Africa. Wetlands Ecology and Management 14:329-348. 